\title{
Oncostatin M promotes proliferation of ovarian cancer cells through signal transducer and activator of transcription 3
}

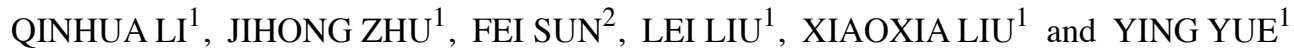 \\ ${ }^{1}$ The First Hospital of Jilin University, ${ }^{2}$ Institute of Frontier Medical Science of Jilin University, \\ Changchun City, Jilin Province 130021, P.R. China
}

Received December 20, 2010; Accepted January 31, 2011

DOI: $10.3892 /$ ijmm.2011.647

\begin{abstract}
Oncostatin M (OSM), a pleiotropic cytokine, has been shown to have distinctive effects in different tissues. In ovarian carcinoma, it is commonly co-expressed together with its receptors but its precise role and the underlying molecular mechanism governing its activity remains unclear. The aim of the present study was to investigate the function of the recombinant human OSM (rH-OSM) in human ovarian cancer. The study demonstrated that $\mathrm{rH}-\mathrm{OSM}$ promotes the proliferation of SKOV3 ovarian cancer cells. Western blot analysis showed that phosphorylated-signal transducer and activator of transcription 3 (p-STAT3), phosphorylatedextracellular signal-regulated protein kinase $1 / 2$ (p-ERK1/2) and p-p38 protein levels increased in the cell lines treated with $\mathrm{rH}-\mathrm{OSM}$. Proliferation in SKOV3 cells induced by rH-OSM was suppressed by inhibitors of p-p38 or p-ERK1/2. Western blot analysis showed that p-STAT3 protein levels decreased in SKOV3 cells treated with inhibitors of p-p38 prior to treatment with rH-OSM. Also, p-STAT3 levels did not increase in cells treated with inhibitors of ERK $1 / 2$ prior to treatment with $\mathrm{rH}-\mathrm{OSM}$. Cell proliferation was moderately increased, and p-ERK1/2 and p-p38 protein expression were similarly affected in STAT3-RNAi knocked-down SKOV3 cells treated with $\mathrm{rH}-\mathrm{OSM}$ compared to the control group. The data demonstrate that the growth-promoting activity of rH-OSM may be mediated through different signaling pathways. ERK1/2 and p38 proteins regulate STAT3 expression in SKOV3 cells, while STAT3 may be pivotal to the proliferation of SKOV3 cells in vitro.
\end{abstract}

Correspondence to: Dr Ying Yue, The First Hospital, Jilin University, Changchun City, Jilin Province 130021, P.R. China E-mail: yying119@126.com

Abbreviations: ERK, extracellular signal-regulated kinase; GAPDH, glyceraldehyde 3-phosphate dehydrogenase; MTT assay, methylthiazoletetrazolium assay; MAPK, mitogen-activated protein kinase; OSM, oncostatin M; rH-OSM, recombinant human oncostatin M; RNAi, RNA interference; STAT3, signal transducer and activator of transcription 3

Key words: epithelial ovarian cancer, oncostatin M, STAT3, ERK1/2,p38

\section{Introduction}

Oncostatin M (OSM) belongs to the family of interleukin (IL)-6 type cytokines produced by monocytes, macrophages, $\mathrm{T}$ cells, neutrophils and several other cell types $(1,2)$. OSM elicits many different biological responses in various cell types, among which the ability to regulate cell growth and differentiation is most notable. OSM has been shown to inhibit the proliferation of a number of cell lines derived from human tumors, including breast tumors and melanomas $(3,4)$. OSM also stimulates the growth of normal fibroblasts (3), normal rabbit vascular smooth muscle cells (5), myeloma cells (6) and AIDS-related Kaposi's sarcoma cells (7).

Increasing evidence suggests that OSM promotes tumor growth and metastasis. Recently, it was demonstrated that OSM could contribute to the proliferation and development of a metastatic phenotype in murine mammary tumors of the carcinoma cell lines M6 (adenocarcinoma) and M6c (metastatic adenocarcinoma) in vivo (8). Furthermore, OSM induced vascular endothelial growth factor (VEGF) production in breast cancer MDA-MB-231 and T47D cells, and increased breast cancer cell detachment and invasive capacity (9). OSM was also shown to down-regulate various melanocyte-lineage (MU, MU-X and EW) antigens targeted by tumor-specific cytotoxic $\mathrm{T}$ lymphocytes, resulting in resistance to immune cytotoxic therapies (10). These data suggest that OSM is unsuitable as a cancer therapeutic drug and suggest that the biological actions of OSM, at least in vitro, may depend on the cell type and context.

Signal transduction by OSM is mainly mediated through the canonical Janus kinase (Jak)/signal transducer and activator of transcription (STAT) pathway (11), by activation of the mitogen-activated protein kinase (MAPK) cascade (12) and through activation of the phosphatidylinositol (PI) 3-kinase pathway (13). Previous studies examined the signaling pathways of OSM in Ba/F3 cells (14), myeloid leukemia M1 cells (15) and MG6 osteoblast cells (16). In Ba/F3 cells, stimulation of gp130 led to cell proliferation. This proliferative response was found to depend on both STAT3 activation and the activation of MAPK and extracellular signal-regulated kinase (ERK). However, in M1 cells, STAT3, but not ERK, was involved in M1 cell differentiation induced by the IL- 6 family of cytokines. Similarly, the IL-6 and OSM-induced differentiation of osteoblast MG63 cells was dependent on STAT3, 
but not on ERK activation. Inhibition of activation of the ERK signaling pathway completely abrogated OSM-induced growth inhibition in MDA-MB231 cells, whereas blocking this ERK signaling pathway had little effect on OSM activity in MCF-7 cells (17). These studies demonstrated that different signaling pathways can be utilized by OSM to regulate cell growth in a cell-type specific manner. However, OSM has recently been shown to activate the protein kinase p38 $(18,19)$, which is generally known to be activated by environmental stressors such as UV exposure, oxidative stress and exposure to pro-inflammatory cytokines (e.g., IL-1 and TNF $\alpha$ ) (20).

OSM-specific receptors are expressed by a wide variety of cell types, including endothelial-, hepatic-, lung- and bone marrow, and many tumor cell lines (21-23) including those of ovarian cancer (24). However, the role and molecular mechanism of OSM in ovarian cancer remains unknown. The purpose of this study was to investigate the possible suppressive or stimulatory role of OSM in the ovarian cancer model of SKOV3 cells, as well as the involvement of the ERK1/2, p38 and STAT3 signaling pathways.

\section{Materials and methods}

Cells and reagents. The human epithelial ovarian cancer cell line, SKOV3, which expresses the OSM specific receptor OSMR/LIFR/gp130 (24), was generously provided by the Central Laboratory of the First Hospital of Jilin University. All cells were cultured in $\mathrm{RFC}_{10}$ [RPMI-1640 with $10 \%$ fetal bovine serum (FBS)] medium and $1 \%$ penicillin and streptomycin in a $5 \% \mathrm{CO}_{2}$-humidified atmosphere at $37^{\circ} \mathrm{C}$. Purified recombinant human $(\mathrm{rH})$-OSM was obtained from PeproTech (Rocky Hill, NJ, USA). The MAPK/ERK kinase (MEK) inhibitor, U0126, was purchased from the Beyotime Institute of Biotechnology (Jiangsu Province, China). The mouse monoclonal antibody against activated p-ERK1/2 and the rabbit polyclonal antibodies to detect inactive STAT3 and p-STAT3 and p-p38 were purchased from Santa Cruz Biotechnology (Santa Cruz, CA, USA). The anti-glyceraldehyde 3-phosphate dehydro-genase (GAPDH) antibody was purchased from the Beyotime Institute of Biotechnology. The p38 inhibitor, SB202190, was purchased from Sigma (St. Louis, MO, USA).

Cell growth curve. Cell proliferation was measured in monolayer cultures grown in Costar 24-well cluster plates. Cells were plated at an initial density of $2.5 \times 10^{3}$ cells $/$ well in $0.5 \mathrm{ml}$ $\mathrm{RFC}_{10}$. The cells were treated with $\mathrm{rH}-\mathrm{OSM}(100 \mathrm{ng} / \mathrm{ml})$ in $0.5 \mathrm{ml}$ medium with $2 \% \mathrm{FBS}, 24 \mathrm{~h}$ after initial seeding. Cells of the control group were treated with an equal volume of RPMI-1640 in $0.5 \mathrm{ml}$ medium with $2 \%$ FBS. The culture medium was refreshed every 2 days. After 6 days of treatment, cells were trypsinized and viable cell numbers were counted.

Cell cycle analysis. Cell cycle distribution was analyzed from monolayer cultures in 6-well Costar cluster plates by flow cytometry. Cells were plated at an initial density of $1 \times 10^{6}$ cells/well in $2 \mathrm{ml} \mathrm{RFC} \mathrm{R}_{10}$. $\mathrm{rH}$-OSM $(100 \mathrm{ng} / \mathrm{ml})$ was added in $2 \mathrm{ml}$ medium supplemented with $2 \% \mathrm{FBS}, 24 \mathrm{~h}$ after initial seeding. Cells of the control group were treated in an equal volume of RPMI-1640 in 2 ml medium with $2 \%$ FBS. For measurements, cells were trypsinized, rinsed with PBS, fixed with $70 \%$ ethanol at $4{ }^{\circ} \mathrm{C}$ overnight and treated with ribonuclease (RNase) A $(0.02 \mathrm{mg} / \mathrm{ml})$ in the dark, at room temperature, for $30 \mathrm{~min}$. Cells were resuspended in propidium iodide (PI) $(0.05 \mathrm{mg} / \mathrm{ml})$ and analyzed with flow cytometry (Becton-Dickinson). DNA histograms were analyzed using the ModFit LT V2.0 software. For each sample, at least $10^{4}$ events were recorded.

Determination of apoptosis by Hoechst 33342/PI staining. Cells were treated with $100 \mathrm{ng} / \mathrm{ml} \mathrm{rH}-\mathrm{OSM}$ in medium with $2 \% \mathrm{FBS}$ for $72 \mathrm{~h}$ in a 6-well plate. Cells of control group were treated with an equal volume RPMI-1640 in $0.5 \mathrm{ml}$ medium with $2 \%$ FBS. The cells were harvested by trypsinization, washed and resuspended in RPMI-1640 medium at a density of $1 \times 10^{6}$ cells $/ \mathrm{ml}$. Next, the cell suspension was incubated with Hoechst $33342(1 \mu \mathrm{g} / \mathrm{ml})$ at $37^{\circ} \mathrm{C}$ for $5 \mathrm{~min}$ and then with PI $(5 \mu \mathrm{g} / \mathrm{ml})$ in the dark at $4^{\circ} \mathrm{C}$ for $30 \mathrm{~min}$, and analyzed by flow cytometry (Becton-Dickinson).

Growth inhibition assay. SKOV3 cells were plated at 3000 cells/well in 96-well plates in $\mathrm{RFC}_{10}$ with $1 \%$ penicillin and streptomycin in a $5 \% \mathrm{CO}_{2}$-humidified atmosphere at $37^{\circ} \mathrm{C}$. The following day, the media were replaced by RPMI-1640 with $2 \% \mathrm{FBS}$ and the cells were treated with $100 \mathrm{ng} / \mathrm{ml}$ rH-OSM. Cells of the control group were treated with an equal volume of RPMI-1640 in $0.5 \mathrm{ml}$ medium with $2 \%$ FBS. Cell proliferation was assessed by the methylthiazoletetrazolium (MTT) assay. At the desired experimental time points, $20 \mu \mathrm{l}$ of $5 \mathrm{mg} / \mathrm{ml}$ MTT were added to the cells, which were then incubated for $4 \mathrm{~h}$ in a humidified $/ 5 \% \mathrm{CO}_{2}$ atmosphere at $37^{\circ} \mathrm{C}$. After vigorous pipetting, $200 \mu \mathrm{l}$ of DMSO was added to each well (to dissolve the formazan salt produced by respiring cells upon metabolizing MTT) and the absorbance was measured at $570 \mathrm{~nm}$ using a microplate reader.

Western blot analysis. SKOV3 cells were plated at $1 \times 10^{6}$ cells/well in 6-well plates in $\mathrm{RFC}_{10}$ with $1 \%$ penicillin and streptomycin in a $5 \% \mathrm{CO}_{2}$-humidified atmosphere at $37^{\circ} \mathrm{C}$. The following day, the media were replaced by RPMI- 1640 with $2 \% \mathrm{FBS}$ and the cells were treated with $100 \mathrm{ng} / \mathrm{ml}$ rH-OSM for different lengths of time. Cells of the control group were treated with an equal volume of RPMI-1640 in $0.5 \mathrm{ml}$ medium with $2 \%$ FBS for different periods of time. Cell protein preparations were run on a $10 \%$ denaturing polyacrylamide gel and transferred to a nitrocellulose membrane. The membrane was incubated for $80 \mathrm{~min}$ at $4^{\circ} \mathrm{C}$ with $5 \%$ non-fat dry milk in Tris buffer (Tris $30 \mathrm{mmol}, \mathrm{pH} 7.6, \mathrm{NaCl}$ $140 \mathrm{mmol}$ and $0.1 \%$ Tween-20) and then incubated overnight with monoclonal antibody. The membrane was then incubated with the secondary antibody and diaminobenzidene (DAB) was used for protein detection.

Transient transfections. Approximately $1 \times 10^{6}$ SKOV3 cells were transiently transfected with $10 \mu \mathrm{g}$ plasmid DNA linking Sh-STAT3 (STAT3-1S: 5'-CACCGCAGCAGCTGAACA ACATGTTCAAGAGACATGTTGTTCAGCTGCTGCT TTTTTG-3'; STAT3-1A: 5'-GATCCAAAAAAGCAGC AGCTGAACAACATGTCTCTTGAACATGTTGTTCA GCTGCTG C-3') with $10 \mu 1$ Lipofectamine 2000 (lip-2000) in Opti-MEM I reduced serum medium (Invitrogen, CA, 


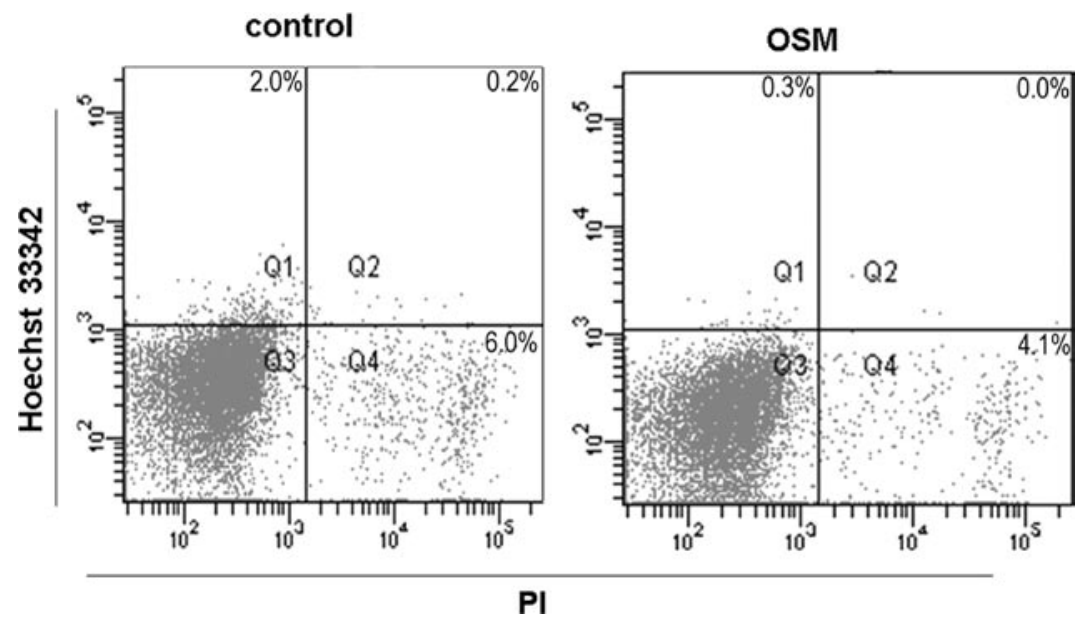

Figure 1. Apoptosis measurement in SKOV3 cells after treatment with rH-OSM, using Hoechst 33342/PI staining. SKOV3 cells were stimulated with or without $100 \mathrm{ng} / \mathrm{ml} \mathrm{rH-OSM}$ for $72 \mathrm{~h}$. The resulting cell suspension was incubated with Hoechst $33342(1 \mu \mathrm{g} / \mathrm{ml})$ at $37^{\circ} \mathrm{C}$ for $5 \mathrm{~min}$ and then with PI $(5 \mu \mathrm{g} / \mathrm{ml})$ in the dark at $4^{\circ} \mathrm{C}$ for $30 \mathrm{~min}$, prior to flow cytometry. The Hoechst positive rate of the cells treated with rH-OSM was similar to that of the control without rH-OSM.

USA) according to the manufacturer's instructions. Transfected cells were named RNAi-vector (control plasmid) and RNAiSTAT3 cells. The cells were incubated under their normal growth conditions and monitored for gene silencing $48 \mathrm{~h}$ after transfection by Western blot.

Statistical analysis. Experiments were performed independently three or more times. The two-tailed Student's t-test and one-way ANOVA (SPSS software version 11.5) were used to analyze statistical significance. P-values $<0.05$ were considered to indicate statistical significance.

\section{Results}

RH-OSM does not induce apoptosis of SKOV3 cells. Previous studies showed that OSM may induce apoptosis of some cell lines derived from human tumors, such as breast, melanoma and lung carcinoma cell lines. To determine whether rH-OSM also induced apoptosis in SKOV3 ovarian cancer cells, we measured the apoptosis rate after treatment with $100 \mathrm{ng} / \mathrm{ml}$ rH-OSM for $72 \mathrm{~h}$ by double staining using Hoechst 33342/PI staining. As shown in Fig. 1, Hoechst 33342 positive nuclear staining of cells treated with $100 \mathrm{nmol}$ of rH-OSM was almost similar to the control group treated without rH-OSM ( $>0.05$, Fig. 1). This result showed that $\mathrm{rH}-\mathrm{OSM}$ can not induce apoptosis in SKOV3 ovarian cancer cells.

RH-OSM induces proliferation of SKOV3 cells. Our results showed a dose-dependent and time-dependent increase in the proliferation of SKOV3 cells treated with rH-OSM. SKOV3 cells were treated with $\mathrm{rH}-\mathrm{OSM}$ from $0-200 \mathrm{ng} / \mathrm{ml}$ for $72 \mathrm{~h}$ and a higher proliferation rate was observed in SKOV3 cells treated with $50-200 \mathrm{ng} / \mathrm{ml} \mathrm{rH-OSM}$ compared to those treated with $0 \mathrm{ng} / \mathrm{ml}(\mathrm{P}<0.05$, Fig. 2A). Cells, from days 3 to 6 after treatment with $100 \mathrm{ng} / \mathrm{ml} \mathrm{rH-OSM}$, demonstrated a higher proliferation rate, as assessed by the MTT assay $(\mathrm{P}<0.05$, Fig. 2B). In addition, cell counting revealed that the number of SKOV 3 cells increased from 3 to 6 days after treatment with rH-OSM ( $\mathrm{P}<0.05$, Fig. $2 \mathrm{C})$. Cell cycle analysis showed that
rH-OSM caused a significant increase of cells in G2/M and S phases at $18 \mathrm{~h}$ and $42 \mathrm{~h}$, as compared to the untreated control cells $(\mathrm{P}<0.05$ for both, Fig. 2D).

Protein expression changes in SKOV3 cells induced by $r H-O S M$. Although activation of ERK1/2, p38 and STAT3 by rH-OSM has been shown in several cell types (as discussed in the introduction), it remains unknown whether rH-OSM could induce ERK1/2, p38 and STAT3 activation in ovarian cancer cells. Thus, p-ERK1/2, p-p38 and p-STAT3 protein levels were examined in SKOV3 cells. When stimulated with $100 \mathrm{ng} / \mathrm{ml}$ of rH-OSM for different lengths of time, p-ERK1/2, p-p38 and p-STAT3 levels were found to be increased by rH-OSM stimulation . Increase of p-ERK $1 / 2$ was detected after $15 \mathrm{~min}$, reached a maximal level at $30 \mathrm{~min}$ and slowly declined after $2 \mathrm{~h}$. The levels of p-STAT3 and p-p38 were found to increase gradually by rH-OSM stimulation over time (Fig. 3).

An ERK1/2 inhibitor blocks the rH-OSM-induced STAT3 expression and proliferation of SKOV3 cells. Induction of ERK1/2 activation was observed in SKOV3 cells exposed to rH-OSM (Fig. 3). We assessed whether ERK1/2 activation induced by rH-OSM had an effect on SKOV3 proliferation. To that end, the MEK inhibitor, U0126, which was found to specifically block ERK activation (17), was used. U0126 was utilized to assess the role of the MEK/ERK pathway in rH-OSM induced growth of SKOV3 cells. After treatment of cells with U0126 for 40 min the levels of p-ERK were decreased (Fig. 4A and B). MTT assays showed that U0126 alone had a notable growth inhibitory effect, and the number of cells after treatment with U0126 could not be increased by rH-OSM ( $\mathrm{P}>0.05$, Fig. 4C). Western blot analysis showed that the level of ERK1/2 activation was suppressed by U0126, while p-p38 protein levels were increased after co-stimulation with rH-OSM and U0126 (Fig. 4A and B). The protein levels of p-STAT3 were increased at 15 and $30 \mathrm{~min}$, but the levels at other time points did not change, as compared to the control. These results demonstrate that the rH-OSM-induced STAT3 expression and proliferation in SKOV3 cells is regulated by ERK1/2. 
A

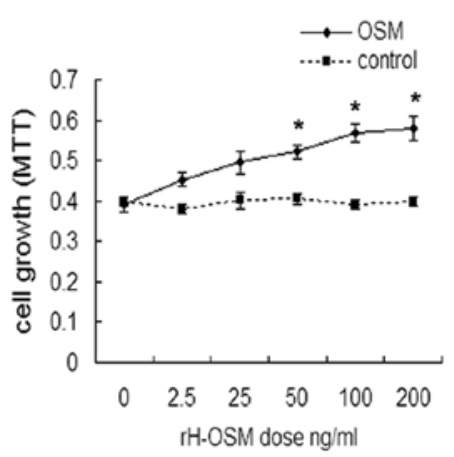

B

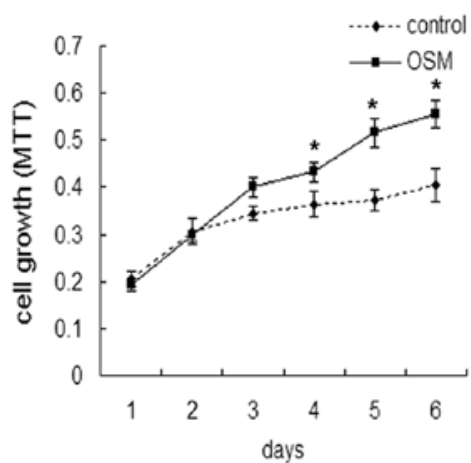

C

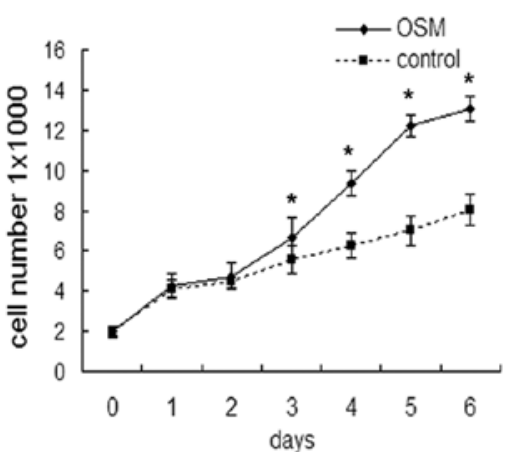

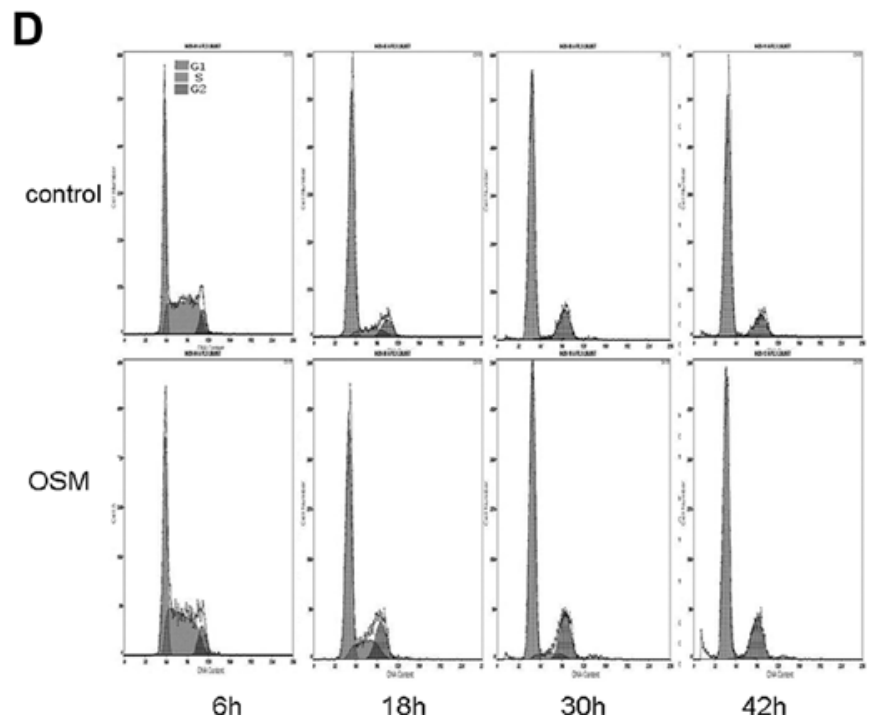

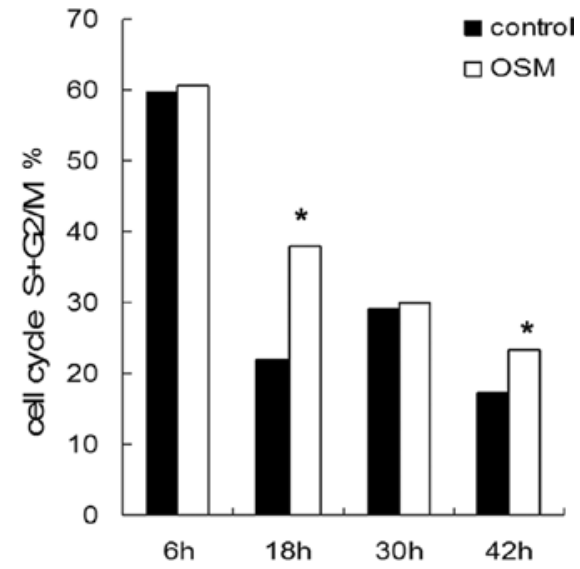

Figure 2. rH-OSM induces proliferation of SKOV3 cells. (A) SKOV3 cells treated with 0-200 ng/ml rH-OSM for $72 \mathrm{~h}$ or (B and C) with $100 \mathrm{ng} / \mathrm{ml} \mathrm{rH}-\mathrm{OSM}$ for 1-6 days. MTT assay (A and B) or cell growth curve (C) after cell treatment with rH-OSM. Cell cycle analysis (D) after cells were treated with $100 \mathrm{ng} / \mathrm{ml}$ rH-OSM for $6,18,30$ or $42 \mathrm{~h}$.
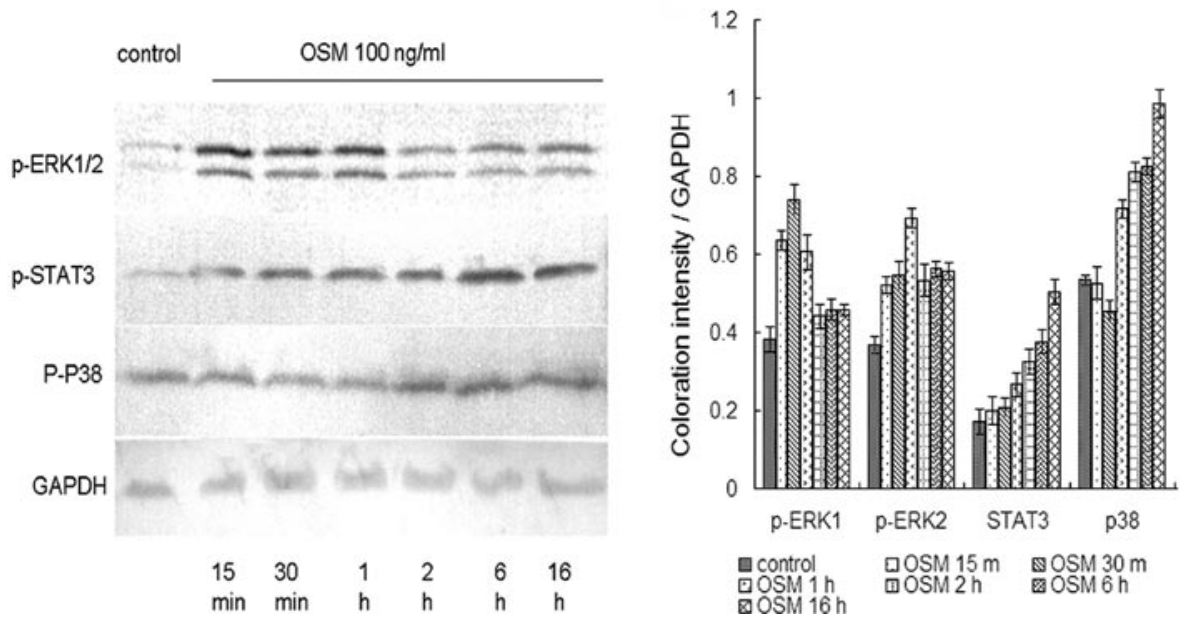

Figure 3. P-ERK1/2, p-p38, and p-STAT3 protein expression levels induced by rH-OSM in SKOV3 cells. SKOV3 cells were treated with $100 \mathrm{ng} / \mathrm{ml} \mathrm{rH}-\mathrm{OSM}$ for different lengths of time. Cells of the control group were treated with an equal volume RPMI-1640 in $0.5 \mathrm{ml}$ medium with $2 \%$ FBS for different periods of time. The protein levels of p-ERK1/2, p-p38, and p-STAT3 were examined though Western blot analysis.

p38 inhibition of the rH-OSM-induced increases in STAT3 expression and proliferation in SKOV3 cells. Activation of p38 was seen in SKOV3 cells after exposure to rH-OSM (Fig. 3). We assessed whether $\mathrm{p} 38$ activation induced by rH-OSM has an effect on SKOV3 proliferation. To that end, an inhibitor of p38 kinase, SB202190, was used. SB202190 (50 nmol/ml) was able to specifically block p38 activation $(25,26)$. Treatment of cells with SB202190 for 40 min lowered the levels of p38 
A

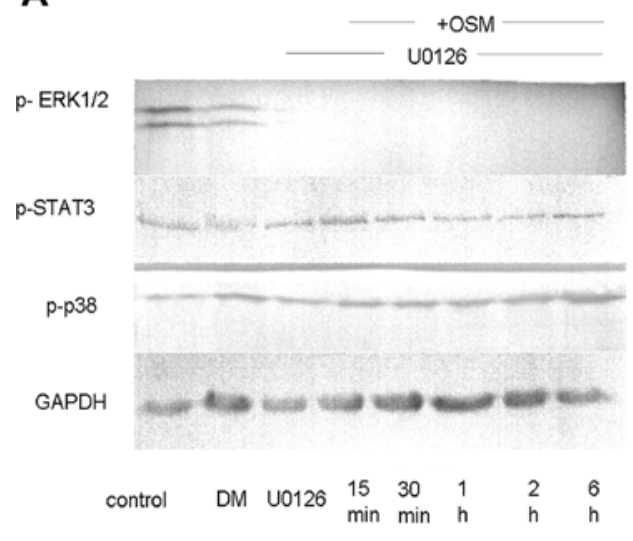

C

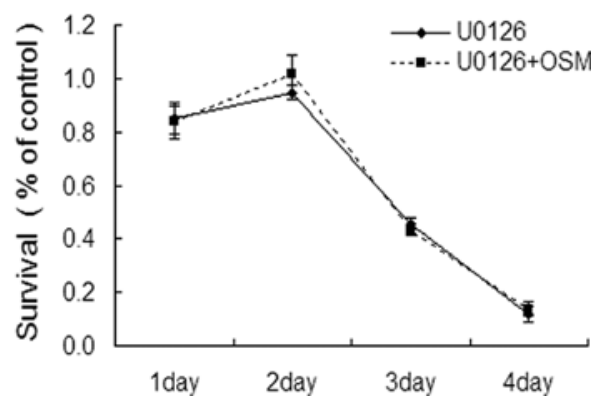

A

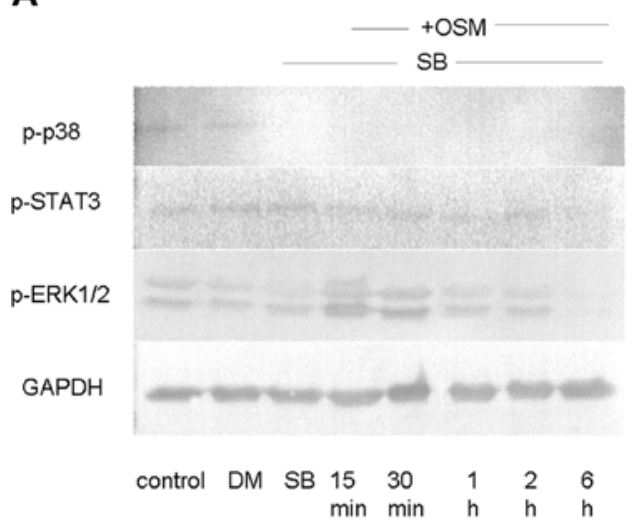

C

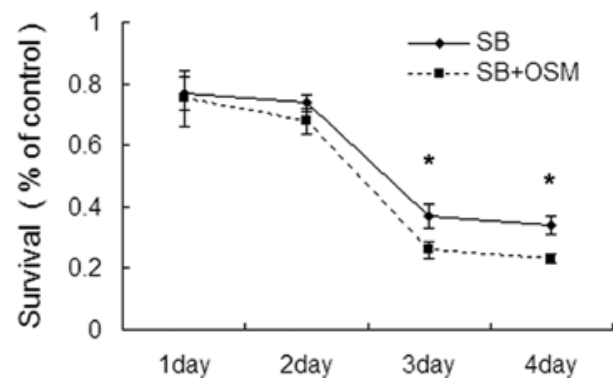

(Fig. 5A and B). Incubation of SKOV3 cells with rH-OSM for 4 days in the presence of $50 \mathrm{nmol} / \mathrm{ml} \mathrm{SB} 202190$, demonstrated that p38 itself has a growth inhibitory effect. Interestingly, the number of SKOV3 cells after 3 days of co-treatment with rH-OSM and SB202190 was lower than with treatment with SB202190 alone $(\mathrm{P}<0.05$, Fig. $5 \mathrm{C})$. Therefore, the prolif-

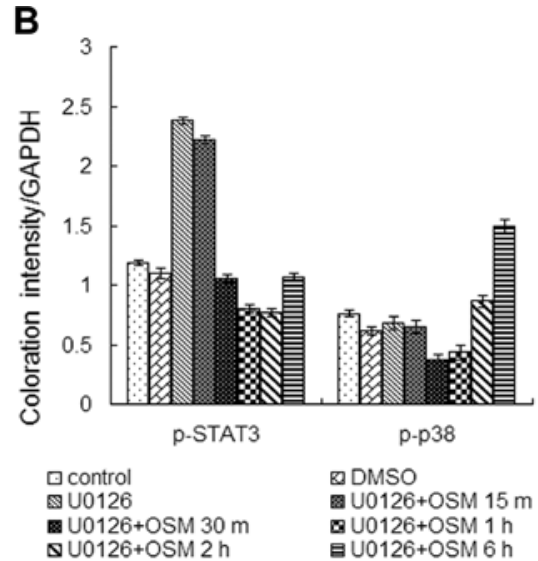

Figure 4. U0126 was utilized to assess the role of p-ERK1/2 in the rH-OSMinduced alterations in the growth and protein expression levels in SKOV3 cells. (A and B) Western blot analysis of the expression levels of p-ERK1/2, p-p38 and p-STAT3 in SKOV3 cells treated with U0126 for 40 min before treatment with $100 \mathrm{ng} / \mathrm{ml} \mathrm{rH}-\mathrm{OSM}$. (C) MTT assays assessing the number of live cells after treatment with U0126 for 40 min prior to treatment with $100 \mathrm{ng} / \mathrm{ml} \mathrm{rH-OSM}$.

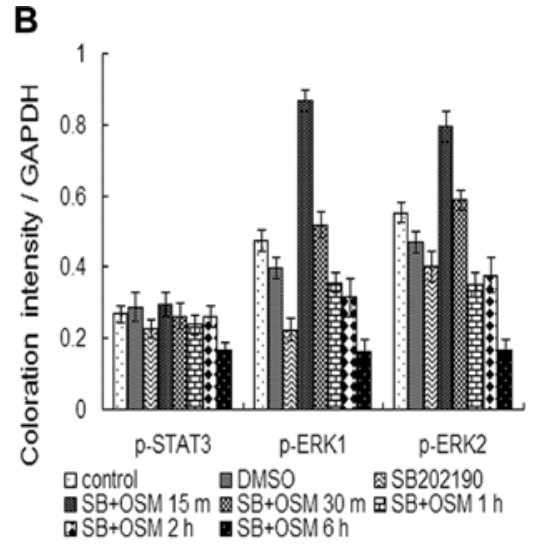

Figure 5. SB202190 was utilized to assess the role of p-p38 in the rH-OSMinduced alterations in the growth and protein expression levels in SKOV3 cells. (A and B) Western blot analysis of the expression levels of p-ERK1/2, p-p38 and p-STAT3 in SKOV3 cells treated with SB202190 for 40 min prior to treatment with $100 \mathrm{ng} / \mathrm{ml} \mathrm{rH-OSM}$. (C) MTT assay assessing the number of live SKOV3 cells after treatment with SB202190 for 40 min prior to treatment with $100 \mathrm{ng} / \mathrm{ml} \mathrm{rH}-\mathrm{OSM}$.

eration of SKOV3 cells induced by $\mathrm{rH}-\mathrm{OSM}$ was reversed by SB202190. Western blot analysis showed (Fig. 5A and B), that the level of p38 activation was lowered by SB202190 stimulation compared to the control. The increase in p-ERK1/2 caused by rH-OSM and SB202190 co-stimulation, was similar to the rH-OSM treatment alone. Interestingly, the protein 


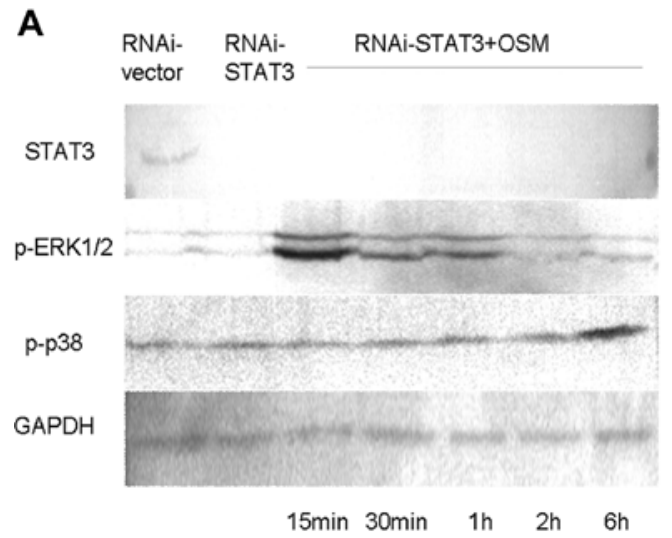

C

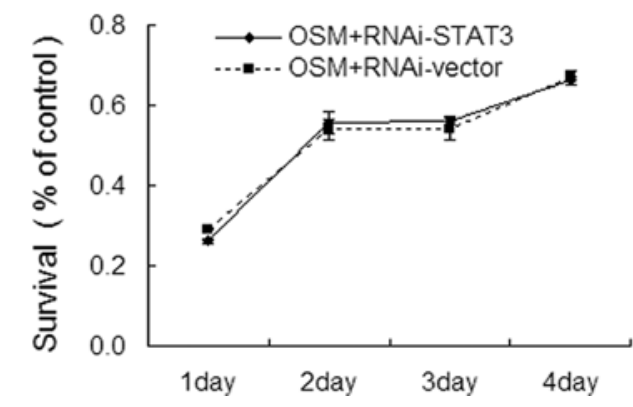

levels of p-STAT3 in response to treatment with $\mathrm{rH}-\mathrm{OSM}$ in the presence of SB202190 gradually decreased over time (Fig. 5A and B). These results demonstrate that $\mathrm{p} 38$ regulates the $\mathrm{rH}-\mathrm{OSM}$-induced alterations in STAT3 expression and proliferation in SKOV3 cells.

STAT3 regulates $\mathrm{rH}$-OSM-induced proliferation in SKOV3 cells. An increase of p-STAT3 expression was seen in SKOV3 cells cultured in the presence of rH-OSM (Fig. 3). We investigated whether the $\mathrm{rH}-\mathrm{OSM}$-induced proliferation is mediated by activation of STAT3 in the SKOV3 ovarian cancer cell line model. To this end, STAT3 was silenced by RNAi. Western blot analysis demonstrated that the protein levels of STAT3 were markedly suppressed (Fig. 6A and B). However, the MTT assay showed that $\mathrm{rH}-\mathrm{OSM}$ did not have an effect on the proliferation of SKOV3 cells in which STAT3 was suppressed (Fig. 6C). Protein levels of p-ERK1/2 and p-p38 in STAT3suppressed cells did not change after incubation with $\mathrm{rH}-\mathrm{OSM}$ (Fig. 6A and B), which suggests that $\mathrm{rH}-\mathrm{OSM}$ may induce the growth of SKOV3 cells though the STAT3 pathway.

\section{Discussion}

The expression of OSM and its receptors has been studied in several human malignancies and cell types. OSM elicits many different biological responses in different cell types. Previous studies suggested the presence of an autocrine loop involving OSM and its receptors in the growth of ovarian carcinoma cells (24), but it was not clear what function such a loop might have. Our findings suggest that $\mathrm{rH}-\mathrm{OSM}$ does not induce apoptosis, but may promote proliferation of SKOV3 cells in vitro (Fig. 2A-C), making rH-OSM a potential survival factor in these cells. Also, as previously mentioned, OSM can serve as

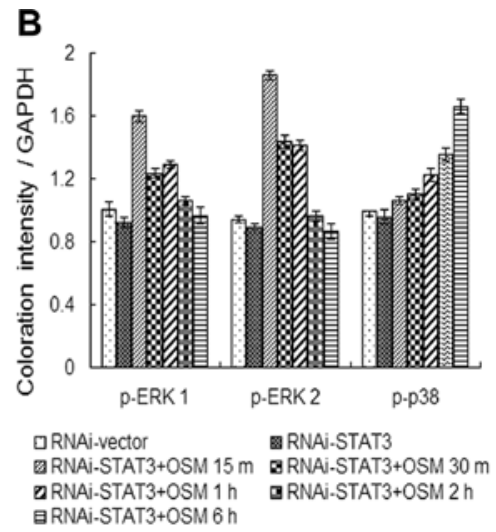

Figure 6. RNAi was utilized to assess the role of STAT3 in the rH-OSMinduced alterations in the growth and protein expression levels in SKOV3 cells. (A and B) Western blot analysis of the expression levels of p-ERK1/2, p-p38, p-STAT3 in SKOV3 cells treated with $100 \mathrm{ng} / \mathrm{ml} \mathrm{rH-OSM}$ in which STAT3 was silenced by RNAi treatment. (C) MTT assays assessing the number of live cells after treatment with $100 \mathrm{ng} / \mathrm{ml} \mathrm{rH}-\mathrm{OSM}$ and STAT3 silencing by RNAi transfection.

an autocrine growth factor for Kaposi's sarcoma cells $(7,27)$ and certain myelomas, plasmacytomas and prostate cancer cells as well (28-30). Thus, the biological actions of OSM, at least in vitro, may depend on the cell type and context.

Previous studies have shown that in certain cell lines OSM induces the activation of STAT3, p38 and ERK. In the present study we demonstrated that in SKOV3 cells, STAT3, p38 and ERK were activated after exposure to rH-OSM. ERK1/2 seems to be important for the rH-OSM-induced STAT3 activation. This notion is supported by the observation that the rH-OSM-induced alteration of STAT3 expression is regulated by exposure to U0126. Our data suggest that STAT3 is positively regulated by ERK1/2 activation in SKOV3 cells. Previous studies have shown that ERK either positively or negatively regulates the activation of STAT3 $(31,32)$. In addition, in our study OSM-induced proliferation and p-STAT3 protein expression was blocked by U0126 in SKOV3 cells. This suggests that OSM-induced proliferation is regulated by ERK1/2 itself or by the signaling cascades of ERK1/2-STAT3.

The activation of the MAPK, p38, was also correlated with the STAT3 response in SKOV3 cells. RH-OSM could induce p38 protein activation in SKOV3 cells. However, the induction of STAT3 activation was counteracted by rH-OSM and even shifted to a decrease when the p38 inhibitor was used. This implies that expression of STAT3 is also mediated by p38. Previous studies have shown that p38 MAPK regulates the activation of STAT3 $(33,34)$. Our data do not completely rule out the possibility that other signaling pathways, in addition to STAT3, ERK and p38, are involved. Whether the rH-OSMinduced p38 increase maintained STAT3 activation through inhibiting other proteins, or whether other rH-OSM-induced pathways are stimulated remains unclear. 
Inhibition of ERK1/2 activation leads to loss of the $\mathrm{rH}-\mathrm{OSM}$-mediated proliferative response and an increased protein level of p-STAT3 in SKOV3 cells. After inhibiting p38 MAPK activation, the rH-OSM-mediated proliferative response also disappeared and was even reversed, while the protein levels of p-STAT3 gradually decreased. The data demonstrate that ERK1/2 and p38 co-regulate the activation of STAT3 and the proliferation in SKOV3 cells. However, we found that alterations in the protein levels of STAT3 occured after treatment with ERK or p38 inhibitors. Therefore, we presume that STAT3 may be a key factor for inducing proliferation of SKOV3 cells in response to $\mathrm{rH}-\mathrm{OSM}$. To test this hypothesis, we inhibited STAT3 gene expression by RNAi. The $\mathrm{rH}-\mathrm{OSM}$-induced proliferative response of SKOV3 cells disappeared, as expected, and the level of p-p38 and $\mathrm{p}$-ERK1/2 remained the same after $\mathrm{rH}-\mathrm{OSM}$ stimulation. STAT3 is therefore, considered an important factor for induction of proliferation (or delay of apoptosis) in SKOV3 cells by rH-OSM. These data demonstrate that the growthpromoting activity of $\mathrm{rH}-\mathrm{OSM}$ can be mediated through different signaling pathways, such as the ERK-STAT3 or the p38-STAT3 signaling pathways. The ERK1/2 and p38 proteins regulate STAT3 expression in SKOV3 cells, while STAT3 may be pivotal for the proliferation of SKOV3 cells in vitro.

\section{Acknowledgements}

We thank Zhiyi Liu, Chongyang Liang, Hongrui Li, Yicheng Liu and Hui Zhou of the Department of Regeneration, Jilin University, for expert technical assistance and scientific discussions. This work was supported by the Science and Technology Department of the Jilin Province Development Plan, Project no. 200705144.

\section{References}

1. Lahiri T, Laporte JD, Moore PE, Panettieri RA and Shore SA: Interleukin-6 family cytokines: signaling and effects in human airway smooth muscle cells. Am J Physiol Lung Cell Mol Physiol 280: 1225-1232, 2001.

2. Grenier A, Dehoux M, Boutten A, Arce-Vicioso M, Durand G, Gougerot-Pocidalo MA and Chollet-Martin S: Oncostatin M production and regulation by human polymorphonuclear neutrophils. Blood 93: 1413-1421, 1999.

3. Horn D, Fitzpatrick WC, Gompper PT, Ochs V, BoltonHansen M, Zarling J, Malik N, Todaro GJ and Linsley PS: Regulation of cell growth by recombinant oncostatin M. Growth Factors 2: 157-165, 1990.

4. Douglas AM, Goss GA, Sutherland RL, Hilton DJ, Berndt MC, Nicola NA and Begley CG: Expression and function of members of the cytokine receptor superfamily on breast cancer cells. Oncogene 14: 661-669, 1997.

5. Grove R I, Eberhardt C, Abid S, Mazzucco C, Liu J, Kiener P, Todaro $\mathrm{G}$ and Shoyab M: Oncostatin M is a mitogen for rabbit vascular smooth muscle cells. Proc Natl Acad Sci USA 90: 823-827, 1993.

6. Zhang XG, Gu JJ, Lu ZY, Yasukawa K, Yancopoulos GD, Turner K, Shoyab M, Taga T, Kishimoto T and Bataille R: Ciliary neurotrophic factor, interleukin 11 , leukemia inhibitory factor and oncostatin $\mathrm{M}$ are growth factors for human myeloma cell lines using the interleukin 6 signal transducer gp130. J Exp Med 179: 1343-1347, 1994.

7. Nair BC, DeVico AL, Nakamura S, Copeland TD, Chen Y, Patel A, O'Neil T, Oroszlan S, Gallo RC and Sarngadharan MG: Identification of a major growth factor for AIDS-Kaposi's sarcoma cells as oncostatin M. Science 255: 1430-1432, 1992.
8. Holzer RG, Ryan RE, Tommack M, Schlekeway E and Jorcyk CL: Oncostatin $M$ stimulates the detachment of a reservoir of invasive mammary carcinoma cells: role of cyclo-oxygenase- 2 . Clin Exp Metastasis 21: 167-176, 2004.

9. Queen MM, Ryan RE, Holzer RG, Keller-Peck CR and Jorcyk CL: Breast cancer cells stimulate neutrophils to produce oncostatin M: potential implications for tumor progression. Cancer Res 65: 8896-8904, 2005.

10. Durda PJ, Dunn IS, Rose LB, Butera D, Benson EM, Pandolfi F and Kurnick JT: Induction of 'antigen silencing' in melanomas by oncostatin $\mathrm{M}$ : down-modulation of melanocyte antigen expression. Mol Cancer Res 1: 411-419, 2003.

11. Hurst SM, McLoughlin RM, Monslow J, Owens S, Morgan L, Fuller GM, Topley N and Jones SA: Secretion of oncostatin $M$ by infiltrating neutrophils: regulation of IL-6 and chemokine expression in human mesothelial cells. J Immunol 169: 5244-5251, 2002.

12. Korzus E, Nagase H, Rydell R and Travis J: The mitogenactivated protein kinase and JAK-STAT signaling pathways are required for an oncostatin M-responsive element-mediated activation of matrix metalloproteinase 1 gene expression. J Biol Chem 272: 1188-1196, 1997.

13. Porter AC and Vaillancourt RR: Tyrosine kinase receptoractivated signal transduction pathways which lead to oncogenesis. Oncogene 17: 1343-1352, 1998.

14. Fukada T, Hibi M, Yamanaka Y, Takahashi-Tezuka M, Fujitani Y, Yamaguchi T, Nakajima K and Hirano T: Two signals are necessary for cell proliferation induced by a cytokine receptor gp130: involvement of STAT3 in anti-apoptosis. Immunity 5: 449-460, 1996.

15. Minami $\mathbf{M}$, Inoue $M$, Wei $S$, Takeda $K$, Matsumoto $M$, Kishimoto T and Akira S: STAT3 activation is a critical step in gp130-mediated terminal differentiation and growth arrest of a myeloid cell line. Proc Natl Acad Sci USA 93: 3963-3966, 1996.

16. Bellido T, Borba VZ, Roberson P and Manolagas SC: Activation of the Janus Kinase/STAT (signal transduction and activatorof transcription) signal transduction pathway by interleukin- 6 type cytokines promotes osteoblast differentiation. Endocrinology 138: 3666-3676, 1997.

17. Li C, Ahlborn TE, Kraemer FB and Liu J: Oncostatin M-induced growth inhibition and morphological changes of MDA-MB231 breast cancer cells are abolished by blocking the MEK/ERK signaling pathway. Breast Cancer Res Treat 66: 111-121, 2001.

18. Hohensinner PJ, Kaun C, Rychli K, Niessner A, Pfaffenberger S, Rega G, Furnkranz A, Uhrin P, Zaujec J, Afonyushkin T, Bochkov VN, Maurer G, Huber K and Wojta J: The inflammatory mediator oncostatin $\mathrm{M}$ induces stromal derived factor-1 in human adult cardiac cell. FASEB J 23: 774-782, 2009.

19. Vollmer S, Kappler V, Kaczor J, Flügel D, Rolvering C, Kato N, Kietzmann T, Behrmann I and Haan C: Hypoxia-Inducible factor 1 is up-regulated by oncostatin $M$ and participates in oncostatin M signaling. Hepatology 50: 253-260, 2009.

20. Repovic P, Mi K and Benveniste EN: Oncostatin M enhances the expression of prostaglandin E2 and cyclooxygenase-2 in astrocytes: synergy with interleukin-1, tumor necrosis factoralpha and bacterial lipopolysaccharide. Glia 42: 433-446, 2003.

21. Thoma B, Bird TA, Friend DJ, Gearing DP and Dower SK: Oncostatin $\mathrm{M}$ and leukemia inhibitory factor trigger overlapping and different signals through partially shared receptor complexes. J Biol Chem 269: 6215-6222, 1994.

22. Mosley B, De Imus C, Friend D, Boiani N, Thoma B, Park LS and Cosman D: Dual oncostatin M (OSM) receptors. Cloning and characterization of an alternative signaling subunit conferring OSM-specific receptor activation. J Biol Chem 271: 32635-32643, 1996.

23. Auguste P, Guillet C, Fourcin M, Olivier C, Veziers J, PouplardBarthelaix A and Gascan H: Signaling of type II oncostatin M receptor. J Biol Chem 272: 15760-15764, 1997.

24. Savarese TM, Campbell CL, McQuain C, Mitchell K, Guardiani R, Quesenberry PJ and Nelson BE: Co-expression of oncostatin $\mathrm{M}$ and its receptors and evidence for STAT3 activation in human ovarian carcinomas. Cytokine 17: 324-334, 2002.

25. Lee JC, Laydon JT, McDonnell PC, Gallagher TF, Kumar S, Green D, McNulty D, Blumenthal MJ, Heys JR and Landvatter SW: A protein kinase involved in the regulation of inflammatory cytokine biosynthesis. Nature 372: 739-746, 1994.

26. Jiang Y, Chen C, Li Z, Guo W, Gegner JA, Lin S and Han J: Characterization of the structure and function of a new mitogen-activated protein kinase (p38beta). J Biol Chem 271: 17920-17926, 1996. 
27. Miles SA, Martínez-Maza O, Rezai A, Magpantay L, Kishimoto T, Nakamura S, Radka SF and Linsley PS: Oncostatin $M$ as a potent mitogen for AIDS-Kaposi's sarcoma-derived cells. Science 255 $1432-1434,1992$.

28. Nishimoto N, Ogata A, Shima Y, Tani Y, Ogawa H, Nakagawa M Sugiyama H, Yoshizaki K and Kishimoto T: Oncostatin M, leukemia inhibitory factor, and interleukin 6 induce the proliferation of human plasmacytoma cells via the common signal transducer, gp130. J Exp Med 179: 1343-1347, 1994.

29. Westendorf JJ and Jelinek DF: Growth regulatory pathways in myeloma. Evidence for autocrine oncostatin $\mathrm{M}$ expression. $\mathrm{J}$ Immunol 157: 3081-3088, 1996.

30. Mori S, Murakami-Mori K and Bonavida B: Oncostatin M (OM) promotes the growth of DU 145 human prostate cancer cells but not PC-3 or LNCaP, through signaling of the OM specific receptor. Anticancer Res 19: 1011-1015, 1999.

31. Steelman LS, Pohnert SC, Shelton JG, Franklin RA, Bertrand FE and McCubrey JA: JAK/STAT, Raf/MEK/ERK, PI3K/Akt and BCR-ABL in cell cycle progression and leukemogenesis. Leukemia 18: 189-218, 2004
32. Krasilnikov M, Ivanov VN, Dong J and Ronai Z: ERK and PI3K negatively regulate STAT-transcriptional activities in human melanoma cells: implications towards sensitization to apoptosis. Oncogene 22: 4092-4101, 2003.

33. Xu B, Bhattacharjee A, Roy B, Xu HM, Anthony D, Frank DA, Feldman GM and Cathcart MK: Interleukin-13 induction of 15-lipoxygenase gene expression requires p38 mitogen-activated protein kinase-mediated serine 727 phosphorylation of Stat1 and Stat3. Mol Cell Biol 23: 3918-3928, 2003.

34. Ng DC, Long CS and Bogoyevitch MA: A role for the extracellular signal-regulated kinase and p38 mitogen-activated protein kinases in interleukin-1 beta-stimulated delayed signal tranducer and activator of transcription 3 activation, atrial natriuretic factor expression, and cardiac myocyte morphology. J Biol Chem 276: 29490-29498, 2001 